\title{
POLYSEROSITIS AND SEVERE SEPSIS AFTER OPEN SUPRAPUBIC RADICAL PROSTATECTOMY: A CASE REPORT
}

\author{
Mario Sučić ${ }^{1}$, Slaven Ovčariček ${ }^{1}$, Adelina Hrkać ${ }^{1}$, Berislav Mažuran ${ }^{1}$ and Hrvoje Budinčeviće,3 \\ ${ }^{1}$ Sveti Duh University Hospital, Department of Urology, Zagreb, Croatia; \\ ${ }^{2}$ Sveti Duh University Hospital, Department of Neurology, Stroke and Intensive Care Unit, Zagreb, Croatia; \\ 3Josip Juraj University of Osijek, Faculty of Medicine, Osijek, Croatia
}

\begin{abstract}
SUMMARY - Infections are well-known complications of radical prostatectomy. In the United States and Europe, the rates of surgical site infections are generally less than $1 \%$ and of other infections up to $3 \%$. We report a case of a 62 -year-old man who developed severe sepsis with renal insufficiency, paralytic ileus and polyserositis after radical prostatectomy, as a consequence of probable quinolone-resistant bacterial infection. Computed tomography of the abdomen and chest showed polyserositis with bilateral pleural and peritoneal effusions. Treatment with meropenem and other supportive measures resulted in good clinical outcome. This case suggested that severe sepsis with exudative polyserositis was probably caused by mobilization of an infective agent (bacterium) during bladder neck dissection as part of open radical prostatectomy.
\end{abstract}

Key words: Prostatectomy; Prostatic neoplasms; Sepsis; Case reports; Surgical wound infection

\section{Introduction}

Prostate cancer is the second leading cause of cancer-related deaths in men in the western world and the second leading cause of cancer-related deaths among men worldwide ${ }^{1}$. Radical prostatectomy is one of the main treatment options in more than $90 \%$ of cases if the cancer is localized ${ }^{2}$. In the United States and $\mathrm{Eu}-$ rope, the rates of surgical site infections are generally less than $1 \%$ and of other infections up to $3 \%^{3}$. The aim of this case report is to present an unusual complication (polyserositis) of radical prostatectomy.

\section{Case Report}

A 62-year-old man presented to the Department of Urology with pain during urination and elevated

Correspondence to: Mario Sučić, MD, Sveti Duh University Hospital, Department of Urology, Sveti Duh 64, HR-10000 Zagreb, Croatia

E-mail: msucic@gmail.com

Received May 16, 2016, accepted December 14, 2016 prostate specific antigen (PSA) of $21.71 \mathrm{ng} / \mathrm{mL}$. His previous medical history included transrectal prostate puncture due to inflammation in 1986. During the past five years, the patient was periodically taking tamsulosin due to elevated levels of PSA.

Digital rectal examination raised suspicion of prostate neoplasm. Transrectal biopsy demonstrated prostate adenocarcinoma of the right lobe gland (Gleason score 7 of 3/10 needle cores). Skeletal scintigraphy was unremarkable, without signs of metastases. Urine culture was sterile before surgery.

Open retropubic radical prostatectomy was performed with routine perioperative antibiotic prophylaxis with $400 \mathrm{mg}$ of intravenous ciprofloxacin. The surgery lasted for two hours without intraoperative complications and marked drop in red blood cell count. During the first postoperative day, the patient's diuresis was $1200 \mathrm{~mL}$, with serum creatinine level of 212 $\mathrm{mmol} / \mathrm{L}$. On postoperative day 2, a decrease in diuresis was observed $(800 \mathrm{~mL})$, with slight elevation of serum creatinine level $(296 \mathrm{mmol} / \mathrm{L})$, but later during the same day, the patient became anuric despite continued 

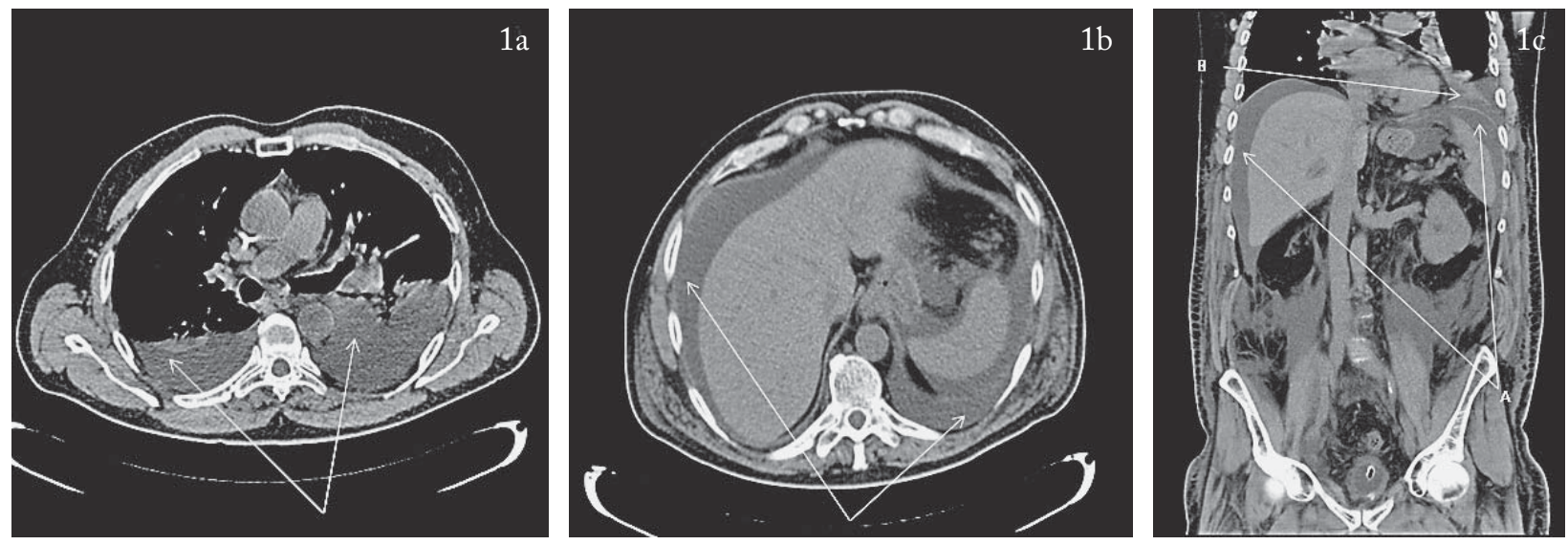

Fig. 1. Transverse plane of computed tomography of the chest shows bilateral pleural effusion (arrows) (a); transverse plane of computed tomography of the abdomen shows bilateral abdominal effusion (arrows) (b); coronal plane of computed tomography of the chest and abdomen shows right pleural effusion and peritoneal effusion (arrows) (c).

stimulation with furosemide. He was also hypotensive, subfebrile $\left(37.3^{\circ} \mathrm{C}\right)$, with elevated levels of inflammatory markers. The $\mathrm{C}$-reactive protein $(\mathrm{CRP})$ value was $312.6 \mathrm{mg} / \mathrm{L}$, leukocytes $14.23 \times 10^{9} / \mathrm{L}$ and serum creatinine level $450 \mathrm{~mm} / \mathrm{L}$. Further, the patient developed paralytic ileus with abdominal distension, edemas of the scrotum and legs, and became dyspneic with tachycardia. Antibiotic therapy with meropenem and hemodialysis were started with other supportive procedures. Computed tomography of the abdomen and chest showed polyserositis with bilateral pleural and peritoneal effusions (Fig. 1). Follow up urine cultures and blood cultures were negative. After second hemodialysis on postoperative day 3 , the patient began to urinate. During the next few days, the patient showed gradual clinical improvement with decline of inflammatory markers.

Surgical wound healed primarily and urine catheter was removed on day 13 of hospital stay. Histopathologic analysis of the surgically removed prostate revealed adenocarcinoma of the prostate (Gleason score 7, pT3N0Mx) with chronic prostatitis and focal comedonecrosis.

\section{Discussion}

Our case pointed to a very rare but possible complication of radical prostatectomy. Severe sepsis with acute renal failure with paralytic ileus and exudative polyserositis was probably caused by dissemination of a quinolone resistant bacterium, probably ESBL-producing Escherichia coli, during bladder neck dissection as part of radical prostatectomy ${ }^{4}$. The usage of fluoroquinolones is well established in numerous urologic procedures $^{5}$. A single dose of antimicrobial prophylaxis with quinolone, or first- or second-generation cephalosporins seems to be sufficient for prevention of perioperative infections in radical prostatectomy, but recent guidelines recommend usage of fluoroquinolones as an alternative option in prophylaxis ${ }^{6-8}$. The study by Banks et al. showed that $25 \%$ of patients having undergone radical prostatectomy had positive urine cultures despite antimicrobial prophylaxis before radical prostatectomy and five days following radical prostatectomy. Resistance to ciprofloxacin was present in $7 \%$ of cases. The most commonly identified organisms were Pseudomonas aeruginosa, Escherichia coli and Staphylococcus epidermidis ${ }^{9}$. Escherichia coli is the most common organism identified in patients with febrile urine tract infection after transrectal ultrasound-guided biopsy and might be the causative agent behind near-fatal sepsis despite quinolone prophylaxis ${ }^{10}$. The study by Ortega et al. showed that Escherichia coli was the main causal agent of community-acquired bacteremia and the third most frequent pathogen causing nosocomial bloodstream infection with urinary tract infection ${ }^{11}$. In our case, the use of meropenem and other supportive treatment resulted in good clinical outcome. The study by Ortega et al. suggests the usage of antibiotics with activity against cephalosporin-re- 
sistant isolates such as carbapenem or tigecycline, especially in cases of severe sepsis with risk factors for fluoroquinolone resistant or ESBL-producing strains ${ }^{11}$.

In conclusion, we would like to point out that severe sepsis with polyserositis might be caused by mobilization of infective agent (bacterium) during bladder neck dissection as part of radical prostatectomy. In patients that are unable to use cephalosporins for antimicrobial prophylaxis before radical prostatectomy, quinolone antibiotics should be used with increased caution.

\section{References}

1. Hudson BD, Kulp KS, Loots GG. Prostate cancer invasion and metastasis: insights from mining genomic data. Brief Funct Genomics. 2013;12:397-410. doi: 10.1093/bfop/elt021

2. Makarov DV, Trock BJ, Humphreys EB, Mangold LA, Walsh PC, Epstein JI, et al. Updated nomogram to predict pathologic stage of prostate cancer given prostate-specific antigen level, clinical stage, and biopsy Gleason score (Partin tables) based on cases from 2000 to 2005. Urology. 2007;69:1095-101. doi: 10.1016/j.urology.2007.03.042

3. Terai A, Ichioka K, Kohei N, Ueda N, Utsunomiya N, Inoue K. Antibiotic prophylaxis in radical prostatectomy: 1-day versus 4-day treatments. Int J Urol. 2006;13:1488-93. doi: 10.1111/j.1442-2042.2006.01597.x

4. McLoughlin LC, McDermott TE, Thornhill JA. Radical prostatectomy in the presence of ongoing refractory ESBL Esche- richia coli bacterial prostatitis. BMJ Case Rep. 2014;2014. doi: 10.1136/bcr-2014-206291

5. Bratzler DW, Dellinger EP, Olsen KM, Perl TM, Auwaerter $\mathrm{PG}$, Bolon MK, et al. Clinical practice guidelines for antimicrobial prophylaxis in surgery. Am J Health Syst Pharm. 2013; 70:195-283. doi: 10.2146/ajhp120568

6. Taoka R, Matsuoka T, Kita Y, Makino Y, Iha K, Soda T, et al. Antimicrobial prophylaxis in radical prostatectomy: single dose versus 1-day treatment. Hinyokika Kiyo. 2010;56:559-63.

7. Stranne J, Aus G, Hansson C, Lodding P, Pileblad E, Hugosson J. Single-dose orally administered quinolone appears to be sufficient antibiotic prophylaxis for radical retropubic prostatectomy. Scand J Urol Nephrol. 2004;38:143-7. doi: 10.1080/00365590310022590

8. Wolf JS Jr, Bennett CJ, Dmochowski RR, Hollenbeck BK, Pearle MS, Schaeffer AJ. Best practice policy statement on urologic surgery antimicrobial prophylaxis. J Urol. 2008;179: 1379-90. doi: 10.1016/j.juro.2008.01.068

9. Banks JA, McGuire BB, Loeb S, Shrestha S, Helfand BT, Catalona WJ. Bacteriuria and antibiotic resistance in catheter urine specimens following radical prostatectomy. Urol Oncol. 2013; 31:1049-53. doi: 10.1016/j.urolonc.2011.12.008

10. Park SC, Lee JW, Rim JS. Robot-assisted laparoscopic radical prostatectomy after fluoroquinolone resistant Escherichia coli sepsis following a transrectal ultrasonography-guided prostate biopsy. Can Urol Assoc J. 2011;5:E56-9. doi: $10.5489 /$ cuaj. 10088

11. Ortega M, Marco F, Soriano A, Almela M, Martinez JA, Munoz A, et al. Analysis of 4758 Escherichia coli bacteraemia episodes: predictive factors for isolation of an antibiotic-resistant strain and their impact on the outcome. J Antimicrob Chemother. 2009;63:568-74. doi: 10.1093/jac/dkn514

Sažetak

\section{POLISEROZITIS ITEŠKA SEPSA NAKON OTVORENE SUPRAPUBIČNE RADIKALNE PROSTATEKTOMIJE: PRIKAZ SLUČAJA}

\section{Sučić, S. Ovčariček, A. Hrkać, B. Mažuran i H. Budinčević}

Infekcije su dobro znane komplikacije radikalne prostatektomije. Učestalost infekcija kirurških rana je općenito manja od $1 \%$, a ostalih infekcija je do 3\%. Prikazujemo slučaj bolesnika u dobi od 62 godine kod kojega se nakon provedene radikalne prostatektomije tijek liječenja komplicirao razvojem teške sepse s renalnom insuficijencijom, paralitičkim ileusom i poliserozitisom, što je bilo vjerojatno uzrokovano bakterijom rezistentnom na kinolone. Kompjutorizirana tomografija abdomena i toraksa pokazala je poliserozitis s obostranim pleuralnim i peritonejskim efuzijama. Liječenje meropenemom i drugim potpornim mjerama rezultiralo je dobrim kliničkim oporavkom i ishodom. Naš slučaj upućuje na to da je teška sepsa s eksudativnim poliserozitisom vjerojatno bila posljedica mobilizacije infektivnog agensa (bakterije) tijekom disekcije vrata mokraćnog mjehura za vrijeme otvorene radikalne prostatektomije.

Ključne riječi: Prostatektomija; Prostata, tumori; Sepsa; Prikazi slučaja; Kirurška rana, infekcija 